\title{
Cellular Redox State Modifications Induced by Bioactive Fe(III)-Cyclophane Complexes Approaching to Selective Therapy Drug Design
}

Alex J Salazar-Medina ${ }^{*}$, Efrain Alday ${ }^{2}$, Ana L Carreño ${ }^{2}$, Javier Hernandez ${ }^{3}$, Gustavo A González-Aguilar ${ }^{1,4}$, Carlos Velázquez ${ }^{2}$ and Enrique F Velázquez-Contreras ${ }^{4}$

${ }^{1}$ Centro de Investigación en Alimentación y Desarrollo, Hermosillo Sonora, 83304 México

${ }^{2}$ Departamento de Ciencias Químico Biológicas, Universidad de Sonora, Hermosillo Sonora, 83000 México

${ }^{3}$ Unidad de Servicios de Apoyo en Resolución Analítica, Universidad Veracruzana, Xalapa, Veracruz, 575 México

${ }^{4}$ Departamento de Investigación en Polímeros y Materiales, Universidad de Sonora, Hermosillo Sonora, 83000 México

\begin{abstract}
Previously we reported the capacity of the bio-inspired $\mathrm{Fe}$ (III) complexes, $\mathrm{Fe}_{2} \mathrm{PO}$ and $\mathrm{Fe}_{2} \mathrm{PC}$, to mimic the activity of superoxide dismutase and peroxidase enzymes, as well as their capacity to reduce the cytotoxicity generated by superoxide radicals in human peripheral blood mononuclear cells, under stress conditions. Based on those findings, we decided to evaluate the cytotoxicity, antioxidant and redox state modulation capacity of $\mathrm{Fe}_{2} \mathrm{PO}$ and $\mathrm{Fe}_{2} \mathrm{PC}$ complexes, pondering them as drug candidates against free radicals unbalance disorders. $\mathrm{Fe}_{2} \mathrm{PO}$ and $\mathrm{Fe}_{2} \mathrm{PC}$ deactivated the ABTS synthetic radical with an $\mathrm{IC}_{50}$ value of $38.4 \pm 0.9 \mu \mathrm{M}$ and $28.9 \pm 0.2$ $\mu \mathrm{M}$, respectively, while against the DPPH radical, the $I_{50}$ value was over the higher concentration tested $(>200$ $\mu \mathrm{M})$ for both complexes. As desirable for any drug candidate, none of the metallic complexes (at 25, 50 and 100 $\mu \mathrm{M}$ ) induced cytotoxicity on M12.C3.F6 cells (a murine B-cell lymphoma model), but differences in the redox state modulation were observed on the basis of fluorescence detection of a $2^{\prime}, 7^{\prime}$-dichlorofluorescin probe by flow cytometry. Cells under normal conditions and preincubated with $\mathrm{Fe}_{2} \mathrm{PO}$ and $\mathrm{Fe}_{2} \mathrm{PC}$ complexes slightly augmented the reactive oxygen species concentration, meanwhile, cells under stress condition preincubated with $\mathrm{H}_{2} \mathrm{O}_{2}$ and metallic complexes, showed a higher augmentation in the reactive oxygen species concentration, in comparison to the controls. Finally, a cellular internalisation assay was performed, showing that $\mathrm{Fe}_{2} \mathrm{PO}$ and $\mathrm{Fe}_{2} \mathrm{PC}$ exert those effects from the outside of the cells. All these results suggest the ability of $\mathrm{Fe}_{2} \mathrm{PO}$ and $\mathrm{Fe}_{2} \mathrm{PC}$ complexes to selectively increase the reactive oxygen species concentration in cells with a free radical unbalance, without inducing mortality in cells under normal conditions.
\end{abstract}

Keywords: Fe(III) complexes; Biomimetic; Antioxidant; Cytotoxicity; Cellular redox state; Selective therapy drug

\section{Introduction}

The catalytic activity of metalloenzymes is generally associated with the presence of transition metals ions (e.g. $\mathrm{Mn}, \mathrm{Fe}, \mathrm{Co}, \mathrm{Ni}, \mathrm{Cu}$ and $\mathrm{Zn}$ ) incorporated into protein structures [1-3]. Metalloenzymes, such as superoxide dismutase (SOD), catalase (CAT) and peroxidase (PO), represent the first line of defence against reactive oxygen species (ROS) in the cellular environment. SOD catalyses the conversion of superoxide $\left(\mathrm{O}_{2}{ }^{-}\right)$to hydrogen peroxide $\left(\mathrm{H}_{2} \mathrm{O}_{2}\right)$ and $\mathrm{O}_{2}$, while the other two enzymes participate in the removal of $\mathrm{H}_{2} \mathrm{O}_{2}$ from the cellular environment $[4,5]$.

Despite living organisms, under normal conditions, continuously generate ROS as a consequence of a large number of biological processes, ROS can overcome the cellular defence and modulation systems, affecting the redox homeostasis and given as a result oxidative stress [4]. Biological systems achieve these processes by using iron, due to its variable redox potential easily tuned by the coordinating ligand selected. The generation of $\mathrm{O}_{2}^{-}$and $\mathrm{H}_{2} \mathrm{O}_{2}$ as a consequence of aerobic respiration is widely reported, as well as how iron catalyses a cascade of one-electron transfer processes to reduced them [6].

A series of metallic complexes of $\mathrm{Fe}(\mathrm{III})$ and $\mathrm{Cu}$ (II) $[7,8]$, based on cyclophane macrocycles as scaffolds [9], has been previously synthesised and reported by our research group. Given the structural resemblance of the synthesised $\mathrm{Fe}(\mathrm{III})$ and $\mathrm{Cu}(\mathrm{II})$ binuclear macrocycle complexes to the active site of some metalloenzymes, we demonstrated the ability of these complexes to act as mimickers of SOD and PO enzymes $[7,8]$. In addition, these $\mathrm{Fe}(\mathrm{III})$ and $\mathrm{Cu}(\mathrm{II})$ complexes provided protection to human peripheral blood mononuclear cells (PBMC) under stress conditions by acting as superoxide scavengers $[7,8]$.
On this basis, it is natural to think in these metallic complexes as possible drugs, candidates to treat free radical unbalance disorders. A reason why, the present study aims to get a deeper knowledge regarding the bioactive properties of iron complexes synthesised in our group, by evaluating how they affect the cellular redox state of a murine B-cell lymphoma (M12.C3.F6) cell line model, considering cell integrity after $\mathrm{H}_{2} \mathrm{O}_{2}$ exposure. In addition to the redox state evaluation, chemical antioxidant assays, cellular toxicity and the ability of the complexes to cross the cell membrane were evaluated.

\section{Materials and Methods}

\section{Chemicals}

Dimethyl sulfoxide, Dulbecco's modified Eagle's medium (DMEM), sodium bicarbonate $(\geq 99.5 \%)$, L-asparagine $(98 \%)$, L-arginine monohydrochloride ( $\geq 98 \%)$, L-glutamine $(200 \mathrm{mM}$ solution), sodium pyruvate ( $100 \mathrm{mM}$ solution), penicillin-streptomycin (1000 units of penicillin and 1 unit of streptomycin per $\mathrm{mL}$ ), ascorbic acid, methanol, ethanol, L-glutathione reduced (GSH), 2,2-diphenyl-

*Corresponding author: Alex J Salazar-Medina, Centro de Investigación en Alimentación y Desarrollo Hermosillo Sonora, 83304 México, Tel: +526622892400; E-mail: alex.salazar.medina@gmail.com

Received July 15, 2017; Accepted July 20, 2017; Published July 25, 2017

Citation: Salazar-Medina AJ, Alday E, Carreño AL, Hernandez J, GonzálezAguilar GA, et al. (2017) Cellular Redox State Modifications Induced by Bioactive Fe(III)-Cyclophane Complexes Approaching to Selective Therapy Drug Design. Med Chem (Los Angeles) 7: 208-212. doi: 10.4172/2161-0444.1000458

Copyright: (C) 2017 Salazar-Medina AJ, et al. This is an open-access article distributed under the terms of the Creative Commons Attribution License, which permits unrestricted use, distribution, and reproduction in any medium, provided the original author and source are credited. 
Citation: Salazar-Medina AJ, Alday E, Carreño AL, Hernandez J, González-Aguilar GA, et al. (2017) Cellular Redox State Modifications Induced by Bioactive Fe(III)-Cyclophane Complexes Approaching to Selective Therapy Drug Design. Med Chem (Los Angeles) 7: 208-212. doi: $10.4172 / 2161-0444.1000458$

1-picryl-hydrazyl (DPPH), 2,2'-azino-bis(3-ethylbenzothiazoline-6sulfonic acid) diammonium salt (ABTS), 3-(4,5-dimethylthiazol-2yl)-2,5-dimethyltetrazolium bromide (MTT), 2',7'-dichlorofluorescin diacetate (DCFH DA; $\geq 97 \%$ ) and propidium iodide were purchased from Sigma Chemicals (St. Louis, MO, USA). Hydrogen peroxide $\left(\mathrm{H}_{2} \mathrm{O}_{2}\right)$ solution $(30 \%)$ was purchased from J. T. Baker Chemicals. Fetal bovine serum was purchased from Gibco. Caffeic acid phenethyl ester (CAPE) was synthesised in our lab based on the procedure of Grunberger et al. [10], as reported by Hernandez et al. [11].

\section{Synthesis of binuclear iron(III) complexes}

To obtain the $\mathrm{Fe}_{2} \mathrm{PO}$ and $\mathrm{Fe}_{2} \mathrm{PC}$ binuclear iron(III) complexes, we previously synthesised 2,9,25,32-tetraoxo-4,7,27,30-tetrakis (carboxymethyl)-1,4,7,10, 24,27,30,33-octaaza-17,40-dioxa[10.1.10.1] paracyclophane and 2,9,25,32-tetraoxo-4,7,27,30tetrakis(carboxymethyl)$1,4,7,10,24,27,30,33$-octaaza[10.1.10.1] paracyclophane, named as PO and PC receptors, respectively. The methodological procedure used was previously reported by Inoue et al. [9]. The purity was confirmed by ${ }^{1} \mathrm{H}-\mathrm{NMR}\left(\mathrm{D}_{2} \mathrm{O} / \mathrm{NaCO}_{3}, \mathrm{pD}=9.5,400 \mathrm{MHz}, \mathrm{DSS}\right)$.

As we reported previously, $\mathrm{Fe}_{2} \mathrm{PO}$ and $\mathrm{Fe}_{2} \mathrm{PC}$ complexes were obtained by dissolving the $\mathrm{PO}$ and $\mathrm{PC}$ receptors in water with a minimum amount of solid $\mathrm{Na}_{2} \mathrm{CO}_{3}$ and mixing both solutions separately with an aqueous solution of $\mathrm{FeCl}_{3} \cdot 6 \mathrm{H}_{2} \mathrm{O}$ in a molar ratio of 1:2 [7]. Immediately, the solution derived from the PO receptor turned reddish as an indicator of the complex formation, meanwhile, the solution derived from the PC receptor turned yellowish as the complexation reaction starts. The melting/decomposition point, elemental analysis and high-resolution electrospray ionisation mass spectra were obtained to corroborate the purity of the $\mathrm{Fe}_{2} \mathrm{PO}$ and $\mathrm{Fe}_{2} \mathrm{PC}$ metallic complexes.

\section{Chemical antioxidant assays}

The chemical antioxidant capacity was determined based on the original procedures of ABTS [12] and DPPH [13] assays, with slight modifications. A dose-response curve was constructed employing different concentrations of $\mathrm{Fe}_{2} \mathrm{PO}$ and $\mathrm{Fe}_{2} \mathrm{PC}$, and the half-maximal inhibitory concentration $\left(\mathrm{IC}_{50}\right)$ was reported. An ABTS ethanolic solution was adjusted to $0.7 \pm 0.02$ absorbance at $754 \mathrm{~nm}$ and a DPPH methanolic solution was also adjusted to $0.7 \pm 0.02$ absorbance at $515 \mathrm{~nm}$. An ABTS radical solution $(245 \mu \mathrm{L})$ was placed in a 96-well microplate (Costar, USA) and $5 \mu \mathrm{L}$ sample solutions $(12.5,25,50,100$ and $200 \mu \mathrm{M}$ ) were added. After $5 \mathrm{~min}$ of incubation, the samples were read at $754 \mathrm{~nm}$. Otherwise, $280 \mu \mathrm{L}$ of DPPH radical was placed in each well of a microplate and samples of $20 \mu \mathrm{L}(12.5,25,50,100$ and 200 $\mu \mathrm{M}$ ) were also added per well. After $30 \mathrm{~min}$ of incubation, the samples were read at $515 \mathrm{~nm}$. In both cases, an Omega spectrophotometer (BMG Labtech Inc., Ortenberf, Germany) was used.

\section{Cellular viability assay}

To evaluate the effect of the $\mathrm{Fe}(\mathrm{III})$ complexes $\left(\mathrm{Fe}_{2} \mathrm{PO}\right.$ and $\left.\mathrm{Fe}_{2} \mathrm{PC}\right)$ on the M12.C3.F6 cell line (murine B-cell lymphoma), cell proliferation was determined using an MTT assay [14] with some modifications [11]. Briefly, cells $\left(1 \times 10^{4}\right.$ per well, $\left.50 \mu \mathrm{L}\right)$ were placed in each well of a 96-well plate (Costar, USA). After $24 \mathrm{~h}$ of incubation at $37^{\circ} \mathrm{C}$ in a $5 \% \mathrm{CO}_{2}$ atmosphere to allow cells attachment, aliquots $(50 \mu \mathrm{L})$ of the medium containing different concentrations of $\mathrm{Fe}(\mathrm{III})$ complexes were added and the cell cultures were incubated for $48 \mathrm{~h}$. Previously, iron complexes were dissolved in Milli- $\mathrm{Q}^{\circ}$ water and filtered through a Millipore $0.22-\mu \mathrm{m}$ filter, and subsequently diluted in the culture medium. We used the cytotoxic drug CAPE as a positive control in the cellular viability assay. In the last $4 \mathrm{~h}$ of the cell culture, $10 \mu \mathrm{L}$ of an MTT solution $(5 \mathrm{mg} / \mathrm{mL})$ was added to each well. The cell viability was assessed by the ability of metabolically active cells to reduce tetrazolium salt to coloured formazan compounds. The formazan crystals were dissolved with acidic isopropyl alcohol. The sample absorbance was measured on a microplate reader (Multiskan EX, ThermoLabSystem) using a test wavelength of $570 \mathrm{~nm}$ and a reference wavelength 630 $\mathrm{nm}$. The effect over cell viability of iron complexes was reported as a proliferation percentage to each concentration evaluated.

\section{Cellular redox state evaluation}

To evaluate the effect of $\mathrm{Fe}_{2} \mathrm{PO}$ and $\mathrm{Fe}_{2} \mathrm{PC}$ metallic complexes on the cellular redox state, we used the B-cell lymphoma M12.C3.F6 cell line as a model, due to its oxidative stress sensibility reflected on its cellular morphology [15]. We evaluated the amount of intracellular ROS in M12.C3.F6 cell line after incubation treatment with $\mathrm{Fe}_{2} \mathrm{PO}$ and $\mathrm{Fe}_{2} \mathrm{PC}$ metallic complexes, in addition to stress induction with $\mathrm{H}_{2} \mathrm{O}_{2}$, based on the methodology reported by Wang and Joseph [16], modified [17] and adapted to cell cytometry as reported by Eruslanov and Kusmartsev [4]. M12.C3.F6 cells were seeded in a 12-well plate (Costar, USA) at $2 \times 10^{5}$ cell $/ \mathrm{mL}$, and after $24 \mathrm{~h}$ of incubation at $37^{\circ} \mathrm{C}$ in a $5 \% \mathrm{CO}_{2}$ atmosphere, $\mathrm{Fe}_{2} \mathrm{PO}$ or $\mathrm{Fe}_{2} \mathrm{PC}$ were added. Followed to a $1 \mathrm{~h}$ incubation at $37^{\circ} \mathrm{C}$ in a $5 \% \mathrm{CO}_{2}$, cells were harvested and washed with cold PBS (pH 7.2) (575 $\times g, 7 \mathrm{~min}, 4^{\circ} \mathrm{C}$ ), which were then resuspended in $1 \mu \mathrm{M}$ of DCFH-DA in cold PBS ( $\mathrm{pH} 7.2$ ). Cells were incubated in the dark for $30 \mathrm{~min}$ at $37^{\circ} \mathrm{C}$ in a $5 \% \mathrm{CO}_{2}$ atmosphere. Afterward, the intracellular oxidative stress was induced using $\mathrm{H}_{2} \mathrm{O}_{2}(1 \mathrm{mM})$ and incubating cells for $5 \mathrm{~min}$ at room temperature. Then, cells were washed with cold PBS $(1700 \mathrm{rpm}$, $\left.7 \mathrm{~min}, 4^{\circ} \mathrm{C}\right)$ and incubated with propidium iodide $(1 \mu \mathrm{g} / \mathrm{mL})$ for $10 \mathrm{~min}$ at room temperature in the dark. Finally, cells were washed with cold PBS (1700 rpm, $7 \mathrm{~min}, 4^{\circ} \mathrm{C}$ ) and resuspended in cold PBS for analysis, considering the fluorescence of an oxidised DCF probe, according to propidium iodide cell exclusion by flow cytometry (FACS Canto II, Becton Dickinson, CA, USA).

\section{Cellular internalisation assay}

In order to determine whether the metallic complexes used in the CAA assays are internalised by M12.C3.F6, we proceeded to detect where both complexes remained after the treatment described here: M12.C3.F6 cells were seeded in a 12-well plate (Costar, USA) at $2 \times 10^{5}$ cells $/ \mathrm{mL}$, and after $24 \mathrm{~h}$ of incubation at $37^{\circ} \mathrm{C}$ in a $5 \% \mathrm{CO}_{2}$ atmosphere, $\mathrm{Fe}_{2} \mathrm{PO}$ or $\mathrm{Fe}_{2} \mathrm{PC}$ complexes were added in 25,50 and 100 $\mu \mathrm{M}$ concentrations to finally incubate for 1 and $3 \mathrm{~h}$, at $37^{\circ} \mathrm{C}$ in a $5 \% \mathrm{CO}_{2}$ atmosphere. After incubation, cells were harvested and centrifuged (1700 rpm, $7 \mathrm{~min}, 4^{\circ} \mathrm{C}$ ). Supernatants were separated and reserved for further analysis. Cell pellets were washed with PBS and resuspended with $1 \mathrm{~mL}$ of absolute ethanol, and to achieve complete lysis, $5 \mathrm{~min}$ of vortexing was applied. Cell lysates were centrifuged to separate soluble material from both the membrane and proteinaceous aggregates. Finally, supernatant from the culture medium and ethanolic lysed cells solutions were analysed by UV-Vis spectroscopy, to detect where the metallic complexes remained after incubation treatments.

\section{Results and Discussion}

\section{Chemical antioxidant assays}

To determine the antioxidant effectiveness of $\mathrm{Fe}_{2} \mathrm{PO}$ and $\mathrm{Fe}_{2} \mathrm{PC}$ both metallic complexes and antioxidant standards (ascorbic acid, GSH and CAPE) were evaluated by ABTS and DPPH radical assays. For the ABTS assay, both metallic complexes were capable of reaching $50 \%$ radical deactivation. $\mathrm{Fe}_{2} \mathrm{PC}$ was slightly more effective at 
Citation: Salazar-Medina AJ, Alday E, Carreño AL, Hernandez J, González-Aguilar GA, et al. (2017) Cellular Redox State Modifications Induced by Bioactive Fe(III)-Cyclophane Complexes Approaching to Selective Therapy Drug Design. Med Chem (Los Angeles) 7: 208-212. doi: $10.4172 / 2161-0444.1000458$

deactivating ABTS radicals in comparison to $\mathrm{Fe}_{2} \mathrm{PO}$, which required higher concentration to achieve the $\mathrm{IC}_{50}$ value (Table 1). Otherwise, by the DPPH assay, an $\mathrm{IC}_{50}$ value of both metallic complexes was not achieved at the tested concentrations. Similar activity behaviour was exhibited by GSH in both assays, with $\mathrm{IC}_{50}$ values consistent to those reported by other authors $[18,19]$. Ascorbic acid and CAPE were both capable of deactivating ABTS and DPPH radicals in a similar manner, however CAPE showed the highest antioxidant activity with an $\mathrm{IC}_{50}$ value under $12.5 \mu \mathrm{M}$ in both assays, with the results in agreement with previous reports $[20,21]$.

Antioxidants can deactivate radicals by two mechanisms, hydrogen atom transfer (HAT) and single electron transfer (SET). ABTS and $\mathrm{DPPH}$ radicals may be neutralised by either $[22,23]$. $\mathrm{Fe}_{2} \mathrm{PO}$ and $\mathrm{Fe}_{2} \mathrm{PC}$ were able to deactivate ABTS radicals in a similar manner, however, DPPH radical deactivation was not efficient enough to inhibit $50 \%$ at the tested concentrations. Since $\mathrm{Fe}_{2} \mathrm{PO}$ and $\mathrm{Fe}_{2} \mathrm{PC}$ deactivate radicals by donating electrons, the $\mathrm{IC}_{50}$ values obtained in the ABTS and DPPH assays represent exclusively the portion of these radicals deactivated by electron transfer. The DPPH radical colour can be dimmed via the HAT and/or SET mechanisms, and the steric accessibility is determinant for its occurrence. Thus, small molecules, like CAPE, have better access to the radical site, showing apparently, a higher antioxidant activity in this assay [24], in comparison to $\mathrm{Fe}_{2} \mathrm{PO}$ and $\mathrm{Fe}_{2} \mathrm{PC}$, which are larger and stiffer complexes. Despite GSH being a small molecule, the fact that a second GSH molecule is required to act as an antioxidant, could be the reason for its reduced efficiency in deactivating the DPPH radical.

\section{Cellular viability assay}

In order to evaluate whether $\mathrm{Fe}_{2} \mathrm{PO}$ and $\mathrm{Fe}_{2} \mathrm{PC}$ exert changes over the redox state of M12.C3.F6 cells, we prior determined the appropriate

\begin{tabular}{|l|c|c|}
\hline \multirow{2}{*}{} & Half-maximal inhibitory concentration $\left(\mathbf{I C}_{50}, \boldsymbol{\mu M}\right)$ \\
\cline { 2 - 3 } & $\mathbf{A B T S}$ & $\mathbf{D P P H}$ \\
\hline $\mathrm{Fe}_{2} \mathrm{PO}$ & $38.4 \pm 0.9$ & $>200.0$ \\
\hline $\mathrm{Fe}_{2} \mathrm{PC}$ & $28.9 \pm 0.2$ & $>200.0$ \\
\hline GSH & $<12.5$ & $>200.0$ \\
\hline Ascorbic Acid & $14.9 \pm 0.9$ & $17.7 \pm 0.9$ \\
\hline CAPE & $<12.5$ & $<12.5$ \\
\hline
\end{tabular}

Data is expressed as mean of three independent experiments performed by triplicate

Table 1: Chemical antioxidant activity of metallic complexes. doses of both metallic complexes without achieving cytotoxicity to the cell culture. We evaluated the effect of $\mathrm{Fe}_{2} \mathrm{PO}$ and $\mathrm{Fe}_{2} \mathrm{PC}$ on cell viability by MTT assay after $48 \mathrm{~h}$ of treatment (Figure 1). We found that none of the metallic complexes significantly affected cell viability at any tested concentration $(0,12.5,25,50$ and $100 \mu \mathrm{M})$. At the highest concentration assessed $(100 \mu \mathrm{M})$, cell culture viability remained over $80 \%$ after both complexes treatments. The control, CAPE, induced a strong antiproliferative effect over M12.C3.F6 cells, even at the lowest tested concentration $(0.63 \mu \mathrm{M})$, reducing cell proliferation by approximately $40 \%$.

These results are in agreement with previous reports of our group, where the cytotoxicity of $\mathrm{Fe}_{2} \mathrm{PO}$ and $\mathrm{Fe}_{2} \mathrm{PC}$ was evaluated in PBMC, obtaining mortality percentages under $1 \%$ after $24 \mathrm{~h}$ of incubation at similar concentrations tested here [7]. These slight differences observed in proliferation percentages could be due to a higher sensibility of M12. C3.F6 cells, in comparison to PBMC.

CAPE, an esterified derivative of caffeic acid, was used as an antiproliferative control compound, since it is a previously reported antiproliferative compound, as well as an effective antioxidant $[11,15]$. CAPE showed a reduction of M12.C3.F6 cell proliferation in $50 \%$ at a concentration of $\sim 1 \mu \mathrm{M}$, suggesting for these data of CAPE, the low antiproliferative effect of $\mathrm{Fe}_{2} \mathrm{PO}$ and $\mathrm{Fe}_{2} \mathrm{PC}$ at $100 \mu \mathrm{M}$.

\section{Cellular redox state evaluation}

With the aim of assessing whether $\mathrm{Fe}_{2} \mathrm{PO}$ and $\mathrm{Fe}_{2} \mathrm{PC}$ complexes induce changes over the M12.C3.F6 cells redox state, we incubated them with different concentrations of metallic complexes, followed or not by oxidative stress induction $\left(\mathrm{H}_{2} \mathrm{O}_{2}\right)$. Cells under normal conditions (with no $\mathrm{H}_{2} \mathrm{O}_{2}$ added) and treated with $\mathrm{Fe}_{2} \mathrm{PO}$ and $\mathrm{Fe}_{2} \mathrm{PC}$ $(25,50$ and $100 \mu \mathrm{M})$ showed a slight increase in intracellular ROS amount, according to the MFI values, in comparison to basal control. A dose-response relationship was not observed for $\mathrm{Fe}_{2} \mathrm{PO}$ treatment, however, as the concentration increased for $\mathrm{Fe}_{2} \mathrm{PC}$ treatment, so did the intracellular ROS concentration. Meanwhile, M12.C3.F6 cells pre-treated with cyclophane complexes and then stressed with $\mathrm{H}_{2} \mathrm{O}_{2}$, exhibited a significant increase in intracellular ROS concentration in all tested concentrations, in comparison with basal M12.C3.F6 cells, $\mathrm{H}_{2} \mathrm{O}_{2}$-stressed cells, as well as with cells pre-treated only with $\mathrm{Fe}_{2} \mathrm{PO}$ and $\mathrm{Fe}_{2} \mathrm{PC}$ (Table 2). CAPE and water were used as reference and dissolvent controls, respectively [15]. a)

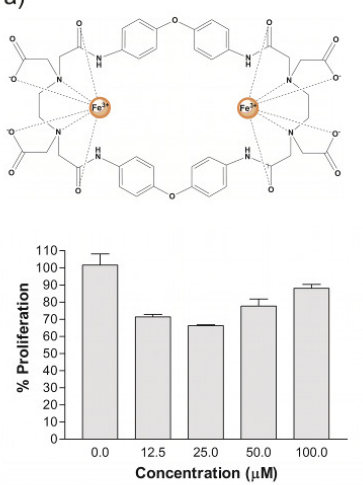

b)
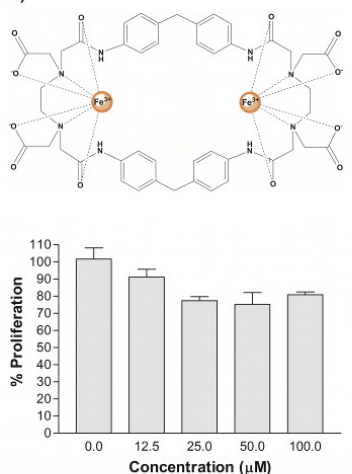
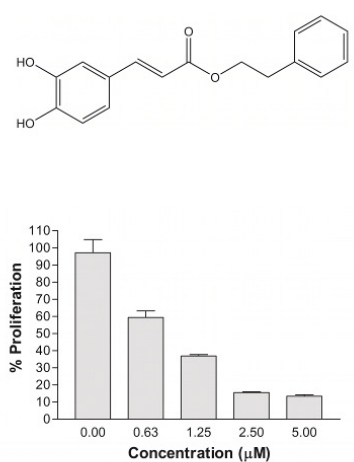

Figure 1: Proliferation percentages of M12.C3.F6 cells cultured with a) $\left.\mathrm{Fe}_{2} \mathrm{PO}, \mathrm{b}\right) \mathrm{Fe}_{2} \mathrm{PC}$ and c) CAPE as a control, at a different concentrations. 
Citation: Salazar-Medina AJ, Alday E, Carreño AL, Hernandez J, González-Aguilar GA, et al. (2017) Cellular Redox State Modifications Induced by Bioactive Fe(III)-Cyclophane Complexes Approaching to Selective Therapy Drug Design. Med Chem (Los Angeles) 7: 208-212. doi: $10.4172 / 2161-0444.1000458$

Modifications in the M12.C3.F6 cells redox state, due to the presence of $\mathrm{Fe}_{2} \mathrm{PO}$ and $\mathrm{Fe}_{2} \mathrm{PC}$ resulted interesting, specifically, in those cells that were pre-treated with metallic complexes, followed by oxidative stress induction with $\mathrm{H}_{2} \mathrm{O}_{2}$. These changes in the cellular redox state could be related to that observed in some studies with cancer cells [25], where systems with similar characteristics, exhibit a major susceptibility under stress conditions to accumulate ROS, ROSpromoters and/or compounds capable of modifying the redox state of the system, such as $\mathrm{Fe}_{2} \mathrm{PO}$ and $\mathrm{Fe}_{2} \mathrm{PC}$.

It is important to note that at the time of the oxidative stress evaluation, a remarkable cellular viability was observed through a propidium iodide staining assay in all experimental conditions tested. $\mathrm{Fe}_{2} \mathrm{PC}$ showed a dose-response relationship, increasing the MFI value with increasing concentration, while $\mathrm{Fe}_{2} \mathrm{PO}$ did not. Differences in MFI values between $\mathrm{Fe}_{2} \mathrm{PO}$ and $\mathrm{Fe}_{2} \mathrm{PC}$ could be attributable to the higher structural flexibility of $\mathrm{Fe}_{2} \mathrm{PO}$, facilitating the interaction between $\mathrm{Fe}(\mathrm{III})$ centres with the medium. Similar results were previously obtained by evaluating the immune response of human embryonic kidney (HEK) 293T cells treated with $\mathrm{Fe}_{2} \mathrm{PO}$ and $\mathrm{Fe}_{2} \mathrm{PC}$. After $8 \mathrm{~h}$ of incubation, cells augmented the expression of genes related to oxidative stress and inflammation, but after $24 \mathrm{~h}$ of incubation, cells regulated themselves by expressing anti-inflammatory genes, resulting in noncytotoxic treatment.

\section{Cellular internalisation assay}

Since metallic complexes, especially $\mathrm{Fe}_{2} \mathrm{PO}$, modify the redox basal state of M12.C3.C6 cells, it was necessary to establish where this effect was taking place, inside or outside the cells. Supernatant culture media after $\mathrm{Fe}_{2} \mathrm{PO}$ and $\mathrm{Fe}_{2} \mathrm{PC}$ metallic complexes treatment were collected by centrifugation, therefore, cell pellets were lysed to obtain ethanolic solutions. UV-Vis spectra of supernatants and cell lysates were recorded. Supernatant culture media of both complexes at all tested conditions (25, 50 and $100 \mu \mathrm{M}$, after 1 and $3 \mathrm{~h}$ incubation), described a similar electronic spectrum to those obtained by $\mathrm{Fe}_{2} \mathrm{PO}$ and $\mathrm{Fe}_{2} \mathrm{PC}$ reference solutions $(25,50$ and $100 \mu \mathrm{M})$, indicating that most of the $\mathrm{Fe}_{2} \mathrm{PO}$ and $\mathrm{Fe}_{2} \mathrm{PC}$ metallic complexes remained in extracellular milieu and were not internalised (Figure 2). In contrast, for ethanolic lysed cell solutions, none of the recorded spectra described the spectra observed for the references, at any of the tested conditions (Figure S1).

Considering the structural features, rigidity and charges of $\mathrm{Fe}_{2} \mathrm{PO}$ and $\mathrm{Fe}_{2} \mathrm{PC}$ metallic complexes, in addition to the relatively short period treatment, a limited or none cell internalisation capacity was expected for both complexes. The UV-Vis spectra showed that $\mathrm{Fe}_{2} \mathrm{PO}$ and $\mathrm{Fe}_{2} \mathrm{PC}$ remained in culture media after incubation treatment and did not in ethanolic cell lysates, concluding that, even when both metallic complexes do not cross the cell membrane, they keep its capacity to modify the cellular redox state of M12.C3.C6 cells, under conditions here tested.

\begin{tabular}{|c|c|c|c|}
\hline \multicolumn{2}{|c|}{ Sample } & \multicolumn{2}{|c|}{ MFI } \\
\hline & & \multirow{2}{*}{\multicolumn{2}{|c|}{$\begin{array}{l}1315 \pm 166 \\
2743 \pm 237\end{array}$}} \\
\hline \multicolumn{2}{|c|}{$\mathrm{H}_{2} \mathrm{O}_{2}^{* *}$} & & \\
\hline & & no $\mathrm{H}_{2} \mathrm{O}_{2}$ & $\mathbf{H}_{2} \mathbf{O}_{2}$ \\
\hline \multirow{3}{*}{$\mathrm{Fe}_{2} \mathrm{PO}$} & $25 \mu \mathrm{M}$ & $1711 \pm 228$ & $3478 \pm 44$ \\
\hline & $50 \mu \mathrm{M}$ & $2276 \pm 174$ & $3443 \pm 19$ \\
\hline & $100 \mu \mathrm{M}$ & $1955 \pm 103$ & $5417 \pm 73$ \\
\hline \multirow[t]{3}{*}{$\mathrm{Fe}_{2} \mathrm{PC}$} & $25 \mu \mathrm{M}$ & $1078 \pm 10$ & $3573 \pm 8$ \\
\hline & $50 \mu \mathrm{M}$ & $1151 \pm 27$ & $3723 \pm 163$ \\
\hline & $100 \mu \mathrm{M}$ & $1579 \pm 91$ & $2470 \pm 165$ \\
\hline
\end{tabular}

"Basal represent cells with no stressor or metallic complex treatment. "* $\mathrm{H}_{2} \mathrm{O}_{2}$ represents cells with $\mathrm{H}_{2} \mathrm{O}_{2} 1$ mM and no metallic complex treatment. Incubation time, $1 \mathrm{~h}$. CAPE $5 \mu \mathrm{M}$ treatment was employed as antioxidant positive control (MFI of 449). Water was used as dissolvent control (treatment v/v \%) with an MFI value of 883. Mean fluorescence intensity (MFI) is expressed in fluorescence intensity arbitrary units (FIAU). Fluorochromes employed: dichloro-dihydro-fluorescein-diacetate (DCFH-DA) and propidium iodide $(\mathrm{PI})$.

Table 2: Cellular redox state evaluation of $\mathrm{Fe}_{2} \mathrm{PO}$ and $\mathrm{Fe}_{2} \mathrm{PC}$ iron complexes on M12.C3.F6 cells.

a)

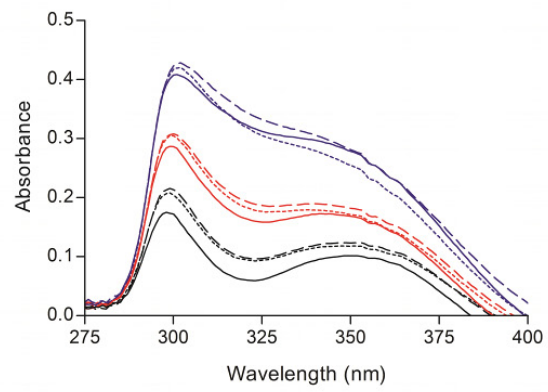

b)

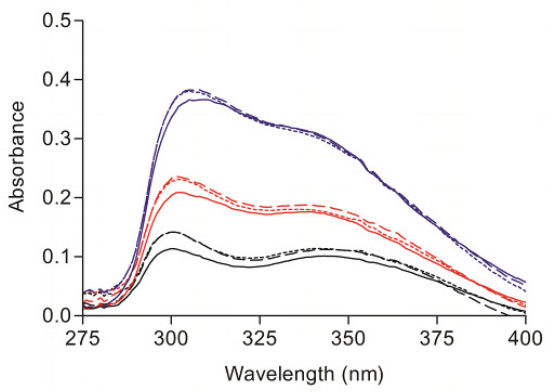

Figure 2: Cellular internalisation assay. Supernatant culture medium (DMEM) after metallic complex treatment. Panel a) Fe $\mathrm{PO}$ and panel b) Fe ${ }_{2} \mathrm{PC}$. Reference solutions (metallic complex dissolved in culture media) are described by solid lines, while dashed and dotted lines represent 1 and $3 \mathrm{~h}$ incubation treatments with metallic complexes, respectively. Black spectra represent a concentration of $25 \mu \mathrm{M}$ metallic complex treatment; red spectra a concentration of $50 \mu \mathrm{M}$ and blue spectra a concentration of $100 \mu \mathrm{M}$. 
Citation: Salazar-Medina AJ, Alday E, Carreño AL, Hernandez J, González-Aguilar GA, et al. (2017) Cellular Redox State Modifications Induced by Bioactive Fe(III)-Cyclophane Complexes Approaching to Selective Therapy Drug Design. Med Chem (Los Angeles) 7: 208-212. doi: 10.4172/2161-0444.1000458

\section{Conclusions}

Based on the structural and electrochemical features of $\mathrm{Fe}_{2} \mathrm{PO}$ and $\mathrm{Fe}_{2} \mathrm{PC}$, the ABTS antioxidant assay was more appropriate for determining their radical scavenger capacity in comparison with the DPPH antioxidant assay. Nevertheless, chemical assays do not reflect what really occurs in a cell system, concerning the redox state. Even when both metallic complexes remained outside M12.C3.F6 cells, intracellular changes in redox state were observed, selectively increasing the reactive oxygen species concentration in cells under induced oxidative stress, but without cytotoxicity effects over cell under normal conditions.

The free radical scavenger capacity comprises a wide range of applications in different industries. The fact that $\mathrm{Fe}_{2} \mathrm{PO}$ and $\mathrm{Fe}_{2} \mathrm{PC}$ complexes exert changes in cellular redox state without inducing cytotoxicity, place them as drug candidates in a new field of investigation to be explored. The selective therapy against cells under inflammatory processes is a fast growth area, with opportunities for complexes with a variety of mechanisms of action, including not only elimination of ROS but also its generation as well, since it is just the biological features of ROS what gives them the capacity to be used as tumour cells killers.

\section{Acknowledgements}

Alex $\mathrm{J}$ Salazar-Medina is a postdoctoral fellow at González-Aguilar's lab. This study was financed by the National Council for Science and Technology (CONACYT) "Fronteras de la Ciencia 563". We also acknowledge the support and facilities obtained through the "Red Temática de Química Supramolecular" agreement 281251 (CONACYT).

\section{References}

1. Bleackley MR, MacGillivray RT (2011) Transition metal homeostasis: from yeast to human disease. Biometals 24: 785-809.

2. Lu N, Chen P, Yang Q, Peng YY (2011) Anti- and pro-oxidant effects of $(+)$-catechin on hemoglobin-induced protein oxidative damage. Toxicology in Vitro 25: 833-838.

3. Poljak-Blazi M, Jaganjac M, Sabol I, Mihaljevic B, Matovina M, et al. (2011) Effect of ferric ions on reactive oxygen species formation, cervical cancer cell lines growth and E6/E7 oncogene expression. Toxicology in Vitro 25: 160-166.

4. Eruslanov E, Kusmartsev S (2009) Identification of ROS using oxidized DCFDA and flow-cytometry, in Advanced Protocols in Oxidative Stress II, Springer 57-72.

5. Salazar-Medina AJ, García-Rico L, García-Orozco KD, Valenzuela-Soto E, Contreras-Vergara CA, et al. (2010) Inhibition by Cu2+ and Cd2+ of a muclass glutathione S-transferase from shrimp Litopenaeus vannamei. Journal of biochemical and molecular toxicology 24: 218-222.

6. Pierre JL, Fontecave M (1999) Iron and activated oxygen species in biology: the basic chemistry. Biometals 12: 195-199.

7. Salazar-Medina AJ, Sugich-Miranda R, Teran-Cabanillas E, Hernández J, González-Aguilar GA, et al. (2013) Antioxidant Capacity of Two Novel Bioactive Fe (III)-Cyclophane Complexes. Molecules 18: 1762-1774.

8. Sugich-Miranda R, Sotelo-Mundo RR, Silva-Campa E, Hernández J, GonzalezAguilar GA, et al. (2010) Antioxidant capacity of binuclear Cu (II)-cyclophanes, insights from two synthetic bioactive molecules. Journal of biochemical and molecular toxicology 24: 379-383.

9. Inoue MB, Velazquez EF, Inoue M, Fernando Q (1997) Molecular recognition of phenethylamine, tyramine and dopamine with new anionic cyclophanes in aqueous media. Journal of the Chemical Society, Perkin Transactions 10: 21132118.

10. Grunberger D, Banerjee R, Eisinger K, Oltz EM, Efros L, et al. (1988)
Preferential cytotoxicity on tumor cells by caffeic acid phenethyl ester isolated from propolis. Experientia 44: 230-232.

11. Hernandez J, Goycoolea FM, Quintero J, Acosta A, Castañeda M, et al. (2007) Sonoran propolis: chemical composition and antiproliferative activity on cancer cell lines. Planta medica 73: 1469.

12. Re R, Pellegrini N, Proteggente A, Pannala A, Yang M, et al. (1999) Antioxidant activity applying an improved ABTS radical cation decolorization assay. Free Radical Biology and Medicine 26: 1231-1237.

13. Brand-Williams W, Cuvelier ME, Berset CL (1995) Use of a free radical method to evaluate antioxidant activity. LWT-Food science and Technology 28: 25-30.

14. Mosmann T (1983) Rapid colorimetric assay for cellular growth and survival: application to proliferation and cytotoxicity assays. Journal of immunological methods 65: 55-63.

15. Carreño AL, Alday E, Quintero J, Pérez L, Valencia D, et al. (2017) Protective effect of Caffeic Acid Phenethyl Ester (CAPE) against oxidative stress. Journal of Functional Foods 29: 178-184.

16. Wang $H$, Joseph JA (1999) Quantifying cellular oxidative stress by dichlorofluorescein assay using microplate reader. Free Radical Biology and Medicine 27: 612-616.

17. Wolfe KL, Liu RH (2007) Cellular antioxidant activity (CAA) assay for assessing antioxidants, foods, and dietary supplements. Journal of agricultural and food chemistry 55: 8896-8907.

18. Wu C, Jia S, Fan G, Li T, Ying R, et al. (2013) Purification and Identification of Novel Antioxidant Peptides from Enzymatic Hydrolysate of Ginkgo biloba Seed Proteins. Food Science and Technology Research 19: 1029-1035.

19. You L, Zhao M, Regenstein JM, Ren J (2011) In vitro antioxidant activity and in vivo anti-fatigue effect of loach (Misgurnus anguillicaudatus) peptides prepared by papain digestion. Food Chemistry 124: 188-194

20. Aniya Y, Koyama T, Miyagi C, Miyahira M, Inomata C, et al. (2005) Free radical scavenging and hepatoprotective actions of the medicinal herb, Crassocephalum crepidioides from the Okinawa Islands. Biological and Pharmaceutical Bulletin 28: 19-23.

21. Salleh NM, Ismail SA, Ibrahim MN (2015) Ibrahim, Radical scavenging activity of lignin extracted from oil palm empty fruit bunch and its effect on GlutathioneS-Transferase enzymes activity. Asian Journal of Pharmaceutical and Clinical Research 8: 81-87.

22. Huang D, Ou B, Prior RL (2005) Prior, The chemistry behind antioxidan capacity assays. Journal of agricultural and food chemistry 53: 1841-1856.

23. Prior RL, Wu X, Schaich K (2005) Schaich, Standardized methods for the determination of antioxidant capacity and phenolics in foods and dietary supplements. Journal of agricultural and food chemistry 53: 4290-4302.

24. Velazquez C, Navarro M, Acosta A, Angulo A, Dominguez Z, et al. (2007) Antibacterial and free-radical scavenging activities of Sonoran propolis. Journal of applied microbiology 103: 1747-1756.

25. Liu J, Wang Z (2015) Increased oxidative stress as a selective anticance therapy. Oxidative medicine and cellular longevity 2015: 1-12. 